전이를 동반한 췌장 신경내분비종양 환자에서 다양한 치료 방법을 시행하여 장기간 생존한 증례

서울대학교 의과대학 내과학 교실 및 간연구소

강형창 · 류지곤 · 이상협 · 김용태

\title{
Long-term Survival in Patient with Metastatic Pancreatic Neuroendo- crine Tumor Treated by Variable Treatment
}

\author{
Hyung Chang Kang, Ji Kon Ryu, Sang Hyub Lee, Yong-Tae Kim \\ Department of Internal Medicine and Liver Research Institute, Seoul National University College of Medicine, Seoul, Korea
}

\begin{abstract}
A 46-year-old female with abnormal radiologic finding was diagnosed with pancreatic neuroendocrine tumor and multiple hepatic metastasis. Molecular targeted therapy (everolimus) and two times of transarterial chemoembolizations (TACE) were performed before pylorus-preserving pancreaticoduodenectomy (PPPD). After 2nd TACE and PPPD, grade 2 pancreatic neuroendocrine tumor was pathologically confirmed. Four times of additional TACE was done. After size increase of several probable hepatic metastasis in the both lobes of liver, laparoscopic left lateral sectionectomy of liver was performed. After two and half years of left lateral sectionectomy, 7th TACE was performed and the patients have survived without further disease progression. This case suggests that patients with pancreatic neuroendocrine tumor and hepatic metastasis can be treated by TACE, primary tumor resection, surgery for liver metastasis and molecular targeted therapy. Therefore, aggressive multidisciplinary approaches need to be considered for long term survival of patients with pancreatic neuroendocrine tumor with hepatic metastasis.
\end{abstract}

Korean J Pancreas Biliary Tract 2017;22(3):141-146

Keywords: Pancreas, Neuroendocrine tumors, Neoplasms, Metastasis
Received Mar. 20, 2017

Revised Apr. 17, 2017

Accepted May. 15, 2017

Corresponding author : Ji Kon Ryu

Department of Internal Medicine and Liver Research Institute, Seoul National University College of Medicine, 101 Daehak-ro, Jongno-gu, Seoul 03080, Korea

Tel. +82-2-2072-1962 Fax. +82-2-762-9662

E-mail: jkryu@snu.ac.kr

This is an Open Access article distributed under the terms of the Creative Commons Attribution Non-Commercial License (http:// Creative Comms Attribut/ creativecommons.org/licenses/by-nc/3.0/) which permits unrestricted non-commercial use, distribution, and reproduction in any medium, provided the original work is properly cited.

Copyright $\odot 2017$ by The Korean Journal of Pancreas and Biliary Tract

\section{서 론}

소화기계 신경내분비종양(gastroenteropancreatic neuroendocrine tumor)은 신경내분비세포에서 기원한 암종으로 소화 관계 및 췌장에서 발생할 수 있다. 신경내분비종양은 근치적 절제술만이 완전 관해를 위한 치료라고 알려져 있지만, 비기
능성 췌장 신경내분비종양 환자의 경우 호르몬 특이적인 증상 이 없기에 많은 비율이 이미 원격전이가 있는 stage IV 상태로 진단이 되어 완전한 절제가 불가능한 경우가 있다. ${ }^{1}$ 질병의 발 생 빈도가 낮기에 진행 경과가 잘 알려져 있지는 않지만, 절제 가 불가능한 전이성 신경내분비종양은 세포감소수술, 항암화 학요법, 분자표적치료, 간동맥화학색전술 등이 증상을 완화 
시키고 생존율을 증가시키는데 도움이 될 수 있다. 이러한 치 료법을 정함에 있어 환자의 증상이나 암종의 전이상태와 분화 도, 분자표적의 여부 등을 고려하여 개별적인 치료법을 선정 해야 한다. ${ }^{2}$ 이들 각각의 치료법의 효과를 입증한 연구는 많지 만, 복합적으로 치료를 진행하는 것의 효과는 명확히 알려지 지 않은 부분이 있다.

저자들은 외부 병원에서 시행한 전산화단층촬영 결과 이상 소견을 주소로 내원하여 다발성 간 전이가 있는 진행성 췌장 신경내분비종양으로 진단되었고, 간동맥화학색전술, 유문보 존췌십이지장절제술, 간 절제술 등을 시행하여 4년 이상 장기 생존 중인 환자 1 예를 경험하여 문헌고찰과 함께 보고한다.

\section{증 례}

46세 여자가 외부 병원에서 시행한 전산화단층촬영 결과 췌 장 두부와 갈고리 돌기에 종양이 발견되었고 간에도 전이가 의심되는 소견으로 본원 소화기내과로 내원하였다. 특별한 통 증은 호소하지 않았고, 체중감소나 황달도 동반되지 않았다. 기저질환으로 당뇨를 가지고 있어 경구혈당강하제 복용 중인 점 이외에 고혈압, 간질환, 결핵 등은 모두 부인하였고 가족력 에서 특이한 소견은 관찰되지 않았다. 신체검진 결과 의식은
명료하였고, 결막 빈혈과 공막 황달은 없었다. 복부는 편평하 였고 장음은 정상 소견이었으며 압통은 없었고, 종괴나 간비 대도 확인되지 않았다. 말초혈액검사 결과 백혈구 $5,200 / \mathrm{mm}^{3}$ (호중구 $64.2 \%$ ), 혈색소 $39.9 \%$, 혈소판 $285,000 / \mathrm{mm}^{3}$ 였다. 일 반화학검사에서 혈청 총 단백 $8.1 \mathrm{~g} / \mathrm{dL}$ 알부민 $4.7 \mathrm{~g} / \mathrm{dL}, \mathrm{AST}$ $26 \mathrm{IU} / \mathrm{L}$, ALT $35 \mathrm{IU} / \mathrm{L}$, 총 빌리루빈 $0.4 \mathrm{mg} / \mathrm{dL}$, blood urea nitrogen $11 \mathrm{mg} / \mathrm{dL}$, 크레아티닌 $0.77 \mathrm{mg} / \mathrm{dL}$, 알칼리성 포스파타 제 $35 \mathrm{IU} / \mathrm{L}, \gamma$-GT $18 \mathrm{IU} / \mathrm{L}$ 였다. 암표지자 검사에서는 CA 19-9 $<1.0 \mathrm{U} / \mathrm{mL}$ (0-37)로 정상이었고, 크로모그라닌A $535.01 \mathrm{ng} /$ $\mathrm{mL}$ (24-97)로 증가되어 있었다. 또한 복부 전산화단층촬영과 복부 자기공명영상에서 췌장 갈고리돌기(uncinate process)에 $3.3 \mathrm{~cm}$ 크기의 조영증강이 잘 되는 종괴와 간에서 전이로 의심 되는 다발성 결절들이 관찰되었다(Fig. 1).

췌장 갈고리돌기 부분과 간 분절 6 부분에 대해서 각각 조직 생검을 실시하였다. 췌장 병리조직 검사 결과 크로모그라닌 A 와 시냅토파이신(synaptophysin) 면역염색 양성이었고 비정 형 상피세포 클러스터가 관찰되었으며, 간 병리조직검사 결과 낮은 유사분열활성도(mitotic activity)의 상피양 종양(epitheloid tumor)으로 확인되어 분화도가 좋은 췌장 신경내분비종 양과 함께 간 전이가 있을 가능성이 높다고 진단하였다. Mammalian target of rapamycin (mTOR) 억제제인 everolim-
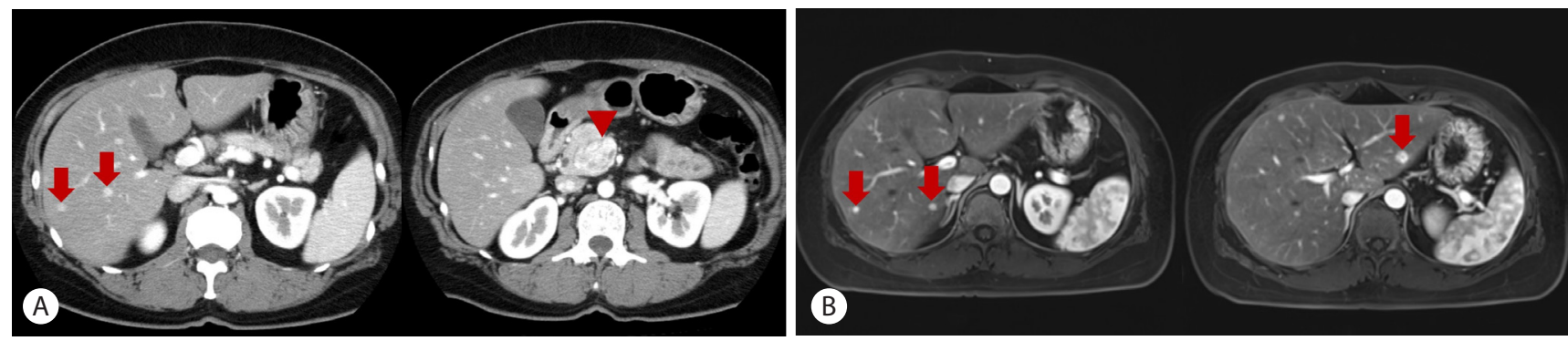

Fig. 1. (A) Initial abdominal computed tomography findings. Multiple hepatic nodules were detected which indicate multiple liver metastasis (arrows). A $33 \mathrm{~mm}$ sized enhanced mass is detected in the uncinate process and pancreatic head (arrow head). (B) Initial magnetic resonance imaging finding of multiple hepatic nodules (arrows).
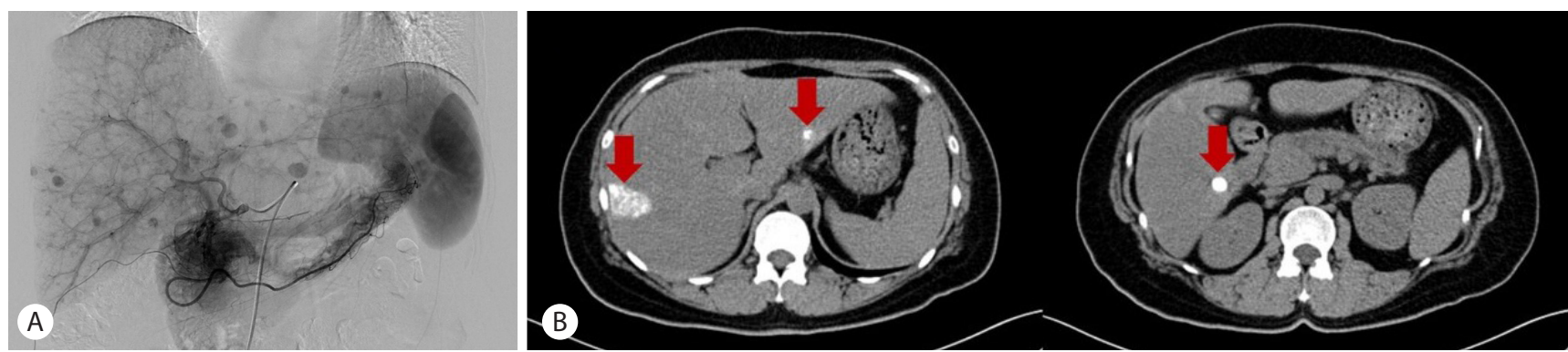

Fig. 2. (A) First transarterial chemoembolization for liver metastasis. Multiple hypervascular tumors are demonstrated on angiography. (B) Follow up abdominal computed tomography after second transarterial chemoembolization. Lipiodol uptakes in the both lobe of liver are detected (arrows). 

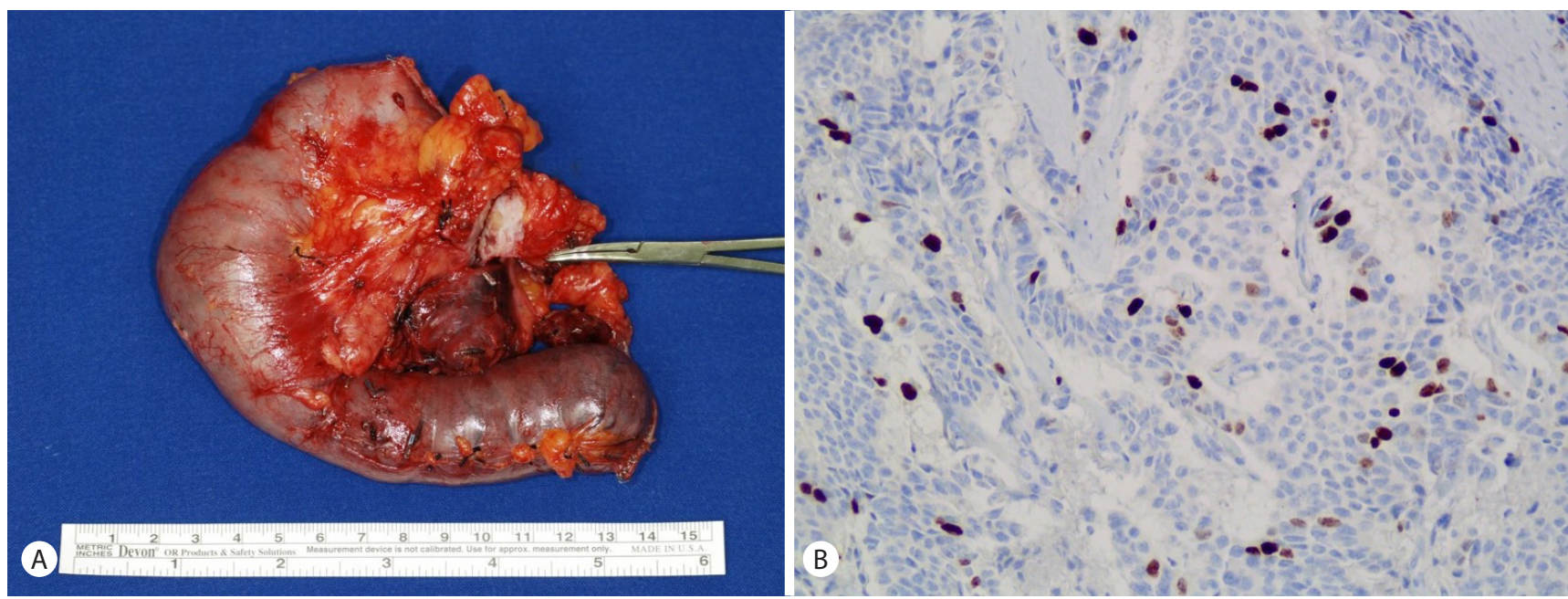

Fig. 3. (A) Gross specimen finding of pylorus-preserving pancreaticoduodenectomy. (B) $7.56 \%$ of the tumor cells revealed positive reactivity to Ki-67 immunohistochemistry (Ki-67 stain, $\times 200)$.
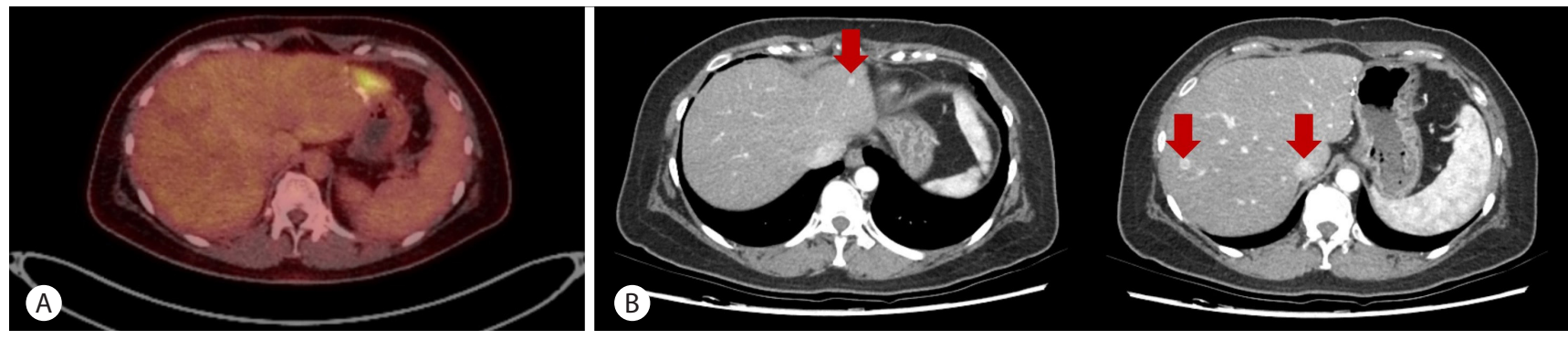

Fig. 4. (A) Follow up positron emission tomography-computed tomography finding after three times of transarterial chemoembolization (TACE). A metastatic mass was detected in the liver left lobe after 1 year of TACE (arrow). (B) Follow up abdominal computer tomography findings after pyloruspreserving pancreaticoduodenectomy and left lateral sectionectomy. Multiple recurred liver nodules were detected on arterial phase (arrows) 4 years after initial diagnosis.

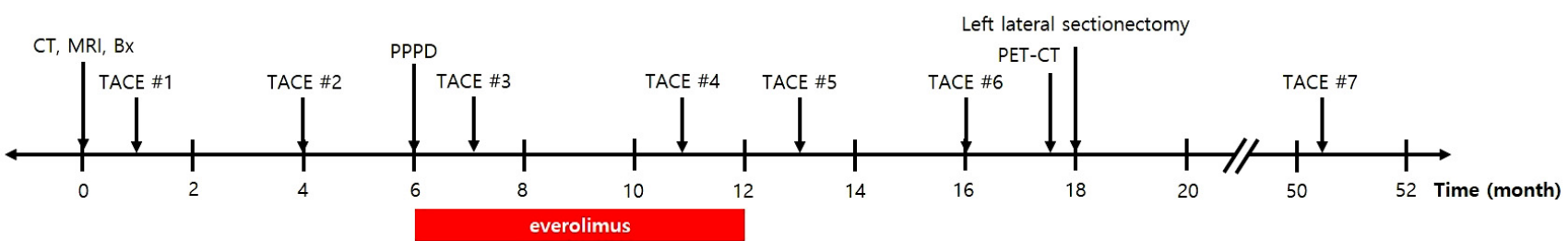

Fig. 5. Flow chart of patient management. CT, computed tomography; MRI, magnetic resonance imaging; Bx, biopsy; TACE, transarterial chemoembolization; PPPD, pylorus-preserving pancreaticoduodenectomy; PET-CT, positron emission tomography-computed tomography.

$\mathrm{us}$ 를 처방하여 총 6 개월간 유지하였다. 간동맥화학색전술을 두 차례 시행한 후 시행한 추적 전산화단층촬영에서 간의 양 쪽 엽에 리피오돌 흡수 종양이 확인되었고(Fig. 2), 췌장의 종 양이 진행하지 않음을 확인하여 3주 뒤에 유문보존 췌십이지 장절제술을 시행하였다(Fig. $3 \mathrm{~A}$ ). 췌장의 두부에 절제된 크기 $3.0 \times 2.5 \times 2.0 \mathrm{~cm}$ 의 고형성 종괴가 관찰되었다. 병리검사를 진행한 결과 췌장 주위 연부조직에 침윤이 확인되었지만 복강
동맥은 침범하지 않았고, 총 9 개 중 2 개의 림프절에서 전이가 확인되었으며, 기존에 시행한 간 조직생검 결과 간 전이가 확 인되었으므로 American Joint Committee on Cancer 7th 병기 체계에 따라 pT3N1M1으로 stage IV로 확인되었다. 유사분열 (mitosis) 개수는 3/10 high-power fields (HPF), Ki-67 index $7.56 \%$ 로(Fig. $3 \mathrm{~B}$ ) 신경내분비종양 grade 2로 진단하였다. 수 술 후 50 일이 경과한 시점에 세 번째 간동맥화학색전술을 진 
행하였다. 이후 추가로 세 차례의 간동맥화학색전술을 추가적 으로 진행하였으나 수술 이후 1년 후 검사한 positron emission tomography-computed tomography 소견에서 간 좌엽에 국한된 전이성 결절이 확인되었고(Fig. $4 \mathrm{~A}$ ) 전산화단층촬영 결과 간의 좌엽과 우엽에 있는 전이병소들의 크기가 약간 증 가한 것이 확인되어 추가적으로 복강경을 통한 간의 좌외측구 역절제술(left lateral sectionectomy)을 진행하였다. 절제된 샘 플에 대한 병리검사 결과 간으로 전이한 grade 2 의 신경내분 비종양으로 확인되었다. 첫 진단 후 4 년이 경과한 뒤 추적관찰 한 전산화단층촬영 결과 다발성 간 전이가 발견되어(Fig. $4 \mathrm{~B})$ 7 번째 간동맥화학색전술을 시행하였고 현재까지 환자는 진단 이후 4년 이상 특별한 증상 없이 생존 중이다(Fig. 5).

\section{고 찰}

본 증례는 무증상 전산화단층촬영의 이상소견을 주소로 내 원한 46세 여자가 다발성 간 전이를 동반한 췌장 신경내분비 종양으로 진단된 후에 표적치료제의 투여와 함께 6차례의 간 동맥화학색전술과 원발 부위 절제술을 시행하였으나, 간에서 추가적인 전이가 발견되어 간 부분 절제술을 시행하고 질병의 진행이 거의 없어 추가적인 치료 없이 4년째 경과관찰 중 원발 부위의 재발 없이 간 전이가 재발하여 총 7차례의 간동맥화학 색전술을 시행한 환자의 증례이다. 이 환자는 간 전이가 있는 췌장 신경내분비종양에 대해서 간동맥화학색전술, 원발 부위 의 절제, 간의 부분 절제술, 표적치료제 투여 등의 치료법을 복 합적으로 고려하였을 때 질병의 진행을 느리게 유지할 수 있 음을 보여주는 예시라고 할 수 있다.

췌장 신경내분비종양은 그 희소성 때문에 지금까지 진행된 연구가 많지 않다. 2008년에 발표된 췌장 신경내분비종양을 가진 환자에 대한 연구 결과에 따르면, 진단 당시 원격전이가 있는 경우가 $64 \%$, 중앙 생존 기간 24 개월로 확인되었다. ${ }^{1}$ 이 연구는 진단이 확실하지 않고 치료법도 확실하지 않은 시기의 환자를 모두 포함시켰기에 중앙 생존 기간이 낮게 나온 것으 로 보인다. 2009년에 발표된 췌장 신경내분비종양과 간 전이 가 있는 환자 90 명을 대상으로 진행한 연구에 의하면 중앙 생 존 기간은 70 개월이었다. 이 연구는 분화도가 나쁜 grade 3 종 양을 제외한 환자들에게 수술적 치료법을 적용시켰으며, 적극 적인 세포감소수술이 중앙 생존 기간을 올리는 데 도움이 된 다는 사실을 뒷받침한다. ${ }^{3} 2011$ 년 발표된 췌장 신경내분비종 양 환자 425 명의 분석 결과에 따르면 진단 당시에 전이가 있는
IV기 상태가 $66 \%$ 로 기존보다 높게 확인되었고, 이들의 중앙 생존 기간은 69 개월이었다. ${ }^{4}$ 이 연구의 저자들은 췌장 신경내 분비종양 환자의 생존 기간이 길어지는 이유를 다양한 치료방 법을 고려한 다학제적인 접근 방법이라고 보았다. ${ }^{13,4}$

본 증례의 환자는 수술 후 병리검사 결과 유사분열(mitosis) 개수는 3/10 HPF, Ki-67 7.56\%로 확인되어 $2010 \mathrm{WHO}$ 분류 에 따르면 신경내분비종양 grade 2 이다. 기존의 연구 결과에 의하면 grade 2 의 췌장 신경내분비종양의 중앙 생존 기간은 각각 22개월, grade 1을 포함한 IV기 환자를 대상으로 24개월 로 나타났기에, ${ }^{1,3}$ 이 증례에서 수술 후 재발 없이 지내다가 2년 6개월 후 간에서 추가적인 전이가 발생한 점은 드문 경우이다.

이전 연구 결과에 따르면 원발 부위의 종양을 제거한 경우 에 중앙 생존 기간이 149 개월, 간 전이가 일어난 경우 전이된 부분을 절제한 경우에 중앙 생존 기간이 209개월로 이러한 처 치를 시행하지 않은 경우의 49 개월보다 길었다. ${ }^{3}$ 다른 연구 결 과 간동맥화학색전술을 시행한 경우 $1,2,3$ 년 무진행 생존 기 간이 각각 $75 \%, 35 \%, 11 \%$ 였고, ${ }^{5}$ 전체적인 반응률은 $33-67 \%$ 로 다양하게 나타났다. ${ }^{6}$ Falconi 등이 제안한 바에 의하면 간 의 양쪽 엽에 전이가 있거나 간의 $75 \%$ 이상을 침범하였을 경 우에는 전이암 절제술(metastasectomy)이 권고되지 않는다. 양쪽 엽에 전이가 있음에도 전이암 절제술이 가능한 경우로는 전체 종양의 $90 \%$ 이상을 절제할 수 있거나 증상이 있는 경우 에 한정된다. ${ }^{8}$ 하지만 Touzios 등 ${ }^{9}$ 에 의하면 최근 다양한 종류 의 전이암에서 부피감소 수술(debulking surgery)이 생존율을 향상시킴이 알려지고 있으며, 간의 $50 \%$ 이하를 침범한 경우에 는 전이절제술과 고주파절제술(radiofrequency ablation), 간 동맥화학색전술을 복합적으로 적용시킬 수 있다. 본 증례의 경우에는 간의 양쪽 엽에 전이가 확인되었지만 전체 간의 $50 \%$ 이하를 침범하였다고 판단되어 간의 좌외측구역절제술을 시 행하기로 판단하였다. 이후에 추가적인 전이가 발생할 경우에 는 고주파절제술을 적용하는 것도 가능할 것으로 본다.

전이가 일어나 절제가 불가능한 신경내분비종양에 대해서 분자표적치료제를 사용하는 방법이 새로운 치료로 각광받고 있다. 다양한 표적치료제 중 mTOR의 억제를 통해서 종양의 성장, 증식, 혈관신생성을 억제하는 mTOR 저해제인 everolimus는 최근에 항암치료에서 그 효과가 입증되고 있다. 특히 grade 1 과 2의 진행성(절제 불가능 혹은 전이성) 췌장 신경내 분비종양을 대상으로 진행된 RADIANT-3 연구 결과에 따르 면 everolimus를 사용한 환자군의 무진행 생존 기간은 11 개월 로 위약군의 4.6 개월에 비해 두 배 이상 연장되었으며, 통계적 
유의성은 확보되지 않았지만 전체 생존 기간(overall survival) 은 44 개월로 위약군의 37.7 개월에 비해 6.3개월 길어진 것으로 보고되었다. ${ }^{10}$ 마찬가지로 2011년에 진행된 3상 연구 결과에 따르면 고분화도의 진행성 췌장내분비종양 환자를 대상으로 sunitinib을 투여한 결과 무진행 생존 기간이 11.4개월로 위약 군의 5.5 개월에 비해 길었다. ${ }^{11}$ 이를 바탕으로 FDA에서는 2011년에 진행성 췌장내분비종양에 대해 mTOR 저해제인 sunitinib과 everolimus를 사용하는 것을 승인하였다. ${ }^{12}$

이와 같은 기존의 연구 결과에 따르면 본 증례에서 간 전이 가 있는 췌장신경내분비 종양이 4년 이상 장기 생존한 것은 원 발 부위 종양 절제와 간 전이부위의 절제를 통해 종양을 제거 하였고, 간동맥화학색전술과 표적치료제를 복합적으로 적용 시켰기 때문으로 생각할 수 있다.

절제 불가능한 전이성 신경내분비종양에 대해서 소마토스 타틴 유사체인 lanreotide가 항암 효과를 가진다는 사실이 최 근 밝혀지고 있다. CLARINET trial에 따르면, 소마토스타틴 수용체 양성이고 grade 1,2 에 해당하는 전이성 신경내분비종 양을 가진 환자에게 lanreotide를 사용하였을 때 무진행 생존 기간이 18 개월 연장되었다. ${ }^{13}$ 또한 종양이 진행할 가능성이 높 은 고위험군 환자에게 lanreotide와 다른 약제를 동시에 투여 하는 치료의 효과에 대한 연구가 진행 중이다. 본 증례의 경우 진단이 오래 전에 이루어져 lanreotide가 치료에 사용되지는 않았지만, 소마토스타틴 유사체와 everolimus를 병용하여 사 용하는 것도 가능하다고 알려져 있기에 추가적인 치료를 위해 lanreotide 를 사용하는 것도 고려해볼 수 있다. ${ }^{10}$

결론적으로 본 증례보고를 통해서 진단 당시에 다발성 간 전이가 확인된 췌장 신경내분비종양의 경우에 적극적인 국소 치료와 수술을 진행하며 표적치료를 복합적으로 적용시킴으 로써 환자를 4년 이상 장기적으로 생존시킬 수 있다는 것을 알 수 있었다. 환자의 상황에 따라 차이가 있겠지만, 간 전이가 있 는 췌장 신경내분비종양 환자의 경우 적극적인 원발 부위 절 제술과 전이 부위 절제술, 국소적 치료 및 표적치료를 복합적 으로 진행한다면 생존율을 높이는 데에 도움이 될 수 있을 것 이라고 본다.

\section{요 약}

영상검사의 이상소견을 주소로 내원한 46 세 여자 환자가 다 발성 간 전이를 동반한 췌장 신경내분비종양으로 진단되었다. 표적치료제를 투여하였으며 두 차례의 간동맥화학색전술을
시행한 뒤 유문보존췌십이지장절제술을 시행하였다. 종양의 수술적 절제와 병리검사를 시행한 결과 췌장 신경내분비종양 grade 2 로 확인되었다. 수술 이후 4 차례의 간동맥화학색전술 을 추가적으로 시행하였다. 1 년 후 진행한 추적관찰 결과 간의 양쪽 엽에 전이된 종양의 크기가 증가한 것이 확인되어 복강 경을 통한 좌외측구역절제술을 시행하였다. 2년 6개월 경과한 후 추적관찰을 진행한 결과 간 전이가 재발하여 7번째 간동맥 화학색전술을 시행하였고, 현재까지 추가적인 치료를 시행하 지 않고 장기 생존 중이다. 본 증례를 통해 다발성 간 전이가 동반된 췌장내분비종양 환자애서 간동맥화학색전술, 원발 부 위의 절제, 전이 부위 제거 및 분자표적치료 등을 환자의 상태 에 맞게 복합적으로 적용시켜 치료할 수 있다는 것을 알 수 있 었다. 결과적으로 간 전이를 동반한 췌장내분비종양 환자의 경우 다양한 치료방법을 적극적으로 적용시켜 생존 기간을 늘 릴 수 있다고 사료된다.

국문 색인: 췌장, 신경내분비종양, 종양 전이

\section{Conflicts of Interest}

The authors have no conflicts to disclose.

\section{REFERENCES}

1. Yao JC, Hassan M, Phan A, et al. One hundred years after "carcinoid": epidemiology of and prognostic factors for neuroendocrine tumors in 35,825 cases in the United States. J Clin Oncol 2008;26:3063-3072.

2. Chang HM. Consensus guideline for advanced pancreatic neuroendocrine tumor. Korean J Med 2011;80:393-396.

3. Strosberg J, Gardner N, Kvols L. Survival and prognostic factor analysis in patients with metastatic pancreatic endocrine carcinomas. Pancreas 2009;38:255-258.

4. Strosberg JR, Cheema A, Weber J, Han G, Coppola D, Kvols LK. Prognostic validity of a novel American Joint Committee on Cancer Staging Classification for pancreatic neuroendocrine tumors. J Clin Oncol 2011;29:3044-3049.

5. Gupta S, Yao JC, Ahrar K, et al. Hepatic artery embolization and chemoembolization for treatment of patients with metastatic carcinoid tumors: the MD Anderson experience. Cancer J 2003;9:261-267.

6. Gu P, Wu J, Newman E, Muggia F. Treatment of liver metastases in patients with neuroendocrine tumors of gastroesophageal and pancreatic origin. Int J Hepatol 2012;2012:131659.

7. Falconi M, Bartsch DK, Eriksson B, et al. ENETS Consensus Guidelines for the management of patients with digestive neuroendocrine neoplasms of the digestive system: well-differentiated pancreatic non- 
functioning tumors. Neuroendocrinology 2011;95:120-134.

8. Chamberlain RS, Canes D, Brown KT, et al. Hepatic neuroendocrine metastases: does intervention alter outcomes? J Am Coll Surg 2000;190:432-445.

9. Touzios JG, Kiely JM, Pitt SC, et al. Neuroendocrine hepatic metastases: does aggressive management improve survival? Ann Surg 2005;241:776-785; discussion 783-785.

10. Yao JC, Pavel M, Lombard-Bohas C, et al. Everolimus for the treatment of advanced pancreatic neuroendocrine tumors: overall survival and circulating biomarkers from the randomized, phase III RADIANT-3 study. J
Clin Oncol 2016;34:3906-3913.

11. Raymond E, Dahan L, Raoul JL, et al. Sunitinib malate for the treatment of pancreatic neuroendocrine tumors. N Engl J Med 2011;364:501-513.

12. Kunz PL, Reidy-Lagunes $D$, Anthony $L B$, et al. Consensus guidelines for the management and treatment of neuroendocrine tumors. Pancreas 2013;42:557-577.

13. Caplin ME, Pavel M, ćwikła JB, et al. Lanreotide in metastatic enteropancreatic neuroendocrine tumors. N Engl J Med 2014;371:224233. 